\title{
FILMES, COMPREENSÃO E EMPATIA HISTÓRICA: CONTRIBUIÇÕES DE UM ESTUDO EMPÍRICO
}

\author{
FILMS, HISTORICAL UNDERSTANDING AND EMPHATY \\ Contributions of an empiric study
}

Éder Cristiano de Souza ${ }^{1}$

\begin{abstract}
RESUMO: $O$ uso de filmes em aulas de História é temática amplamente debatida e difundida nos estudos sobre Ensino de História. Contudo, é raro encontrar estudos derivados de investigações empíricas para observar os limites e potencialidades da aprendizagem histórica mobilizada em tais atividades. Essa é a proposta do presente artigo, que apresenta parte dos resultados de uma pesquisa sobre a aprendizagem histórica de jovens a partir de filmes em aulas de História, direcionados a partir do conceito de "cognição histórica situada". Propõem-se, então, caminhos para se pensar os filmes no ensino, principalmente a partir dos conceitos de "compreensão histórica" e "empatia histórica", que permitem superar uma visão segundo a qual esta aprendizagem seria resultado exclusivo dos estímulos provocados pela linguagem fílmica.
\end{abstract}

Palavras-Chave: Cognição histórica situada. Empatia histórica. Linguagem fílmica.

\begin{abstract}
The use of films in history classes is a topic widely debated and diffused in the studies about History Teaching. However, it is rare to find studies derived from empirical researches to observe the limits and potentialities of the historical learning mobilized in such activities. This is the proposal of this article, which presents part of the results from a research about historical learning of young people from films in history classes, directed from the concept of "situated historical cognition". Ways of thinking films in education are then proposed, mainly from the concepts of "historical understanding" and "historical empathy", that allow us to overcome a view that this learning would be the exclusive result of the stimuli provoked by the filmic language.
\end{abstract}

Keywords: Situated historical cognition. Historical empathy. Filmic language.

\footnotetext{
1 Professor da Universidade Federal da Integração Latino-Americana e Docente Permanente do Mestrado em História Social da Universidade Estadual de Londrina. Doutor em Educação pela UFPR.
} 


\section{Apresentação}

Diversos estudos atualmente têm problematizado a noção de aprendizagem histórica, ampliando as preocupações para além do foco nos métodos de ensino. Esses estudos tomam por base a concepção de cognição histórica situada (SCHMIDT; BARCA, 2009), definida como uma aprendizagem complexa que mescla a assimilação de determinadas visões a respeito do passado, com uma interpretação do processo de constituição dessas visões. Ou seja, a ideia é que a aprendizagem histórica não se restringe somente a conhecer os produtos resultantes da pesquisa histórica, mas também em assimilar o processo de produção desse conhecimento. Isso se sintetiza na ideia de que é possível uma aprendizagem no âmbito da epistemologia da História.

Este artigo traz resultados de uma investigação sobre cognição histórica situada, desenvolvida no âmbito de minha tese de doutorado, em 2014. O objetivo principal da pesquisa foi compreender como jovens estudantes aprendem História a partir de filmes. No estudo empírico foram exibidas, aos jovens, três produções cinematográficas que abordavam o conceito histórico nazismo, e depois foi aplicada a metodologia do Grupo Focal, quando eles participaram de uma discussão coletiva sobre a temática e expressaram as ideias mobilizadas no decorrer da atividade.

Participaram do estudo onze estudantes, entre 16 e 19 anos de idade, do terceiro ano do Ensino Médio, de um colégio público estadual no município de Araucária - PR. Os filmes "Triunfo da Vontade", "A Queda! As últimas horas de Hitler" e "O Pianista", foram selecionados para compor a investigação, por se tratarem de obras com grande difusão e repercussão, terem complexidade técnica e artística e trazerem pontos de vista divergentes sobre o nazismo.

As problemáticas teóricas concernentes à apropriação dos filmes na produção do conhecimento histórico e no Ensino de História foram debatidas de forma profunda em outros trabalhos (SOUZA, 2012, 2014a, 2014b). Nossa opção, por ora, foi por não discorrer sobre essas temáticas, visto que 
o objeto de análise é a aprendizagem verificada no estudo empírico desenvolvido, e não os limites da linguagem fílmica, nem suas características como obras comerciais ou políticas, de ficção ou documentários. Ainda que esses temas estejam entrelaçados, para efeito de análise, é necessário fazer essa distinção.

As abordagens recorrentes sobre o trabalho com os filmes no ensino da História se direcionam no sentido de conceber a aprendizagem histórica como uma ampliação da memória sobre os feitos históricos ou, então, como desenvolvimento de competências de análise fílmica, a partir do confronto com dados históricos. O que aqui se propõe é distinto de tais concepções, especialmente pela opção de centralizar a abordagem nos sujeitos que aprendem, entendendo que a aprendizagem histórica se relaciona a um conjunto de referências maior do que a relação entre filmes e conhecimento.

O objetivo central da pesquisa foi verificar como os jovens estudantes lidam com a noção de multiperspectividade a partir dos filmes históricos. Contudo, para além dessa questão, foi possível também observar outros aspectos, como o desenvolvimento da compreensão histórica e da empatia histórica. Essas duas conceituações são o foco do presente artigo.

A partir da categoria conceitual "aumento das experiências" (RÜSEN, 2012), analisa-se como a linguagem fílmica contribui e complexifica a cognição histórica situada. O intuito é esclarecer como o desenvolvimento da compreensão histórica se dá de uma forma mais complexa do que simplesmente pelo estímulo audiovisual, contribuindo para avançar no debate sobre a aprendizagem histórica a partir de filmes, levando em conta os fatores mobilizadores da consciência histórica e deixando de focar-se simplesmente na questão da recepção fílmica.

Já o conceito de empatia histórica se relaciona à possibilidade de desenvolvimento de uma compreensão contextualizada do passado, evitando anacronismos e julgamentos parciais. Os dados obtidos no estudo também apontaram elementos que permitiram formular análises a partir deste conceito, e parte dessas considerações também se faz presente neste artigo. 


\section{Da qualificação da plausibilidade das narrativas à complexificação da compreensão histórica por parte dos jovens}

Em um estudo sobre a cognição histórica dos jovens a partir das histórias em quadrinhos, Fronza (2012) evidencia como há uma potencialização das ideias históricas a partir do fator estético que a linguagem propicia na comunicação da História. Entende que esse fator estético não pode ser reduzido à noção de ficcionalização do passado, uma vez que há uma complexificação e sofisticação de ideias históricas, e isso possibilita avanços no sentido da formação de padrões coerentes de formulação de narrativas históricas. Segundo esse mesmo pesquisador, é a plausibilidade das narrativas gráficas que contribui para essa potencialização das ideias históricas.

No estudo desenvolvido, a plausibilidade foi compreendida pelos jovens participantes a partir da relação que estabeleceram entre suas concepções prévias e o que o filme comunicava, sendo desafiada e tornada mais complexa durante o processo, de acordo com os questionamentos que surgiram e com a manifestação de distintos pontos de vista. O primeiro fator destacado nesse processo de qualificação da experiência histórica desses sujeitos foi entendido como a inserção de limites de plausibilidade, a partir dos quais determinados temas se destacaram por se relacionarem, diretamente, às concepções prévias dos estudantes e provocarem mudanças qualitativas em suas ideias históricas.

Trataram-se de padrões não estanques de plausibilidade, que direcionaram a reelaboração da experiência histórica, uma vez que determinadas questões presentes nos filmes foram ignoradas ou simplesmente não levadas em consideração, pois não se adequaram aos seus esquemas de plausibilidade. Contudo, a apreensão de grande volume de informações e sentidos a partir dos filmes foi filtrada por fatores relacionados às suas experiências individuais e coletivas com 0 conhecimento histórico. 
Nesse sentido, a noção de qualificação da experiência histórica precisa ser diferenciada do entendimento superficial, segundo o qual os estímulos audiovisuais potencializariam a aprendizagem, pois essa noção não leva em consideração que tal relação é interpelada pelos fatores mobilizadores da consciência histórica, que possibilitam determinadas apreensões complexas e raciocínios sofisticados, mas também limitam outras apreensões possíveis.

A capacidade de utilizar as experiências históricas para orientação da vida define o que Rüsen chama de "competência narrativa", e seria o foco central da aprendizagem histórica. A ampliação dessa competência se daria por meio das seguintes operações: 1. Aumento das experiências ampliação da memória histórica do indivíduo, ou seja, do acervo de informações/conhecimentos sobre o passado; 2 . Crescimento da subjetividade - quanto mais o sujeito agrega conhecimentos históricos à sua memória, maior sua percepção de mundo; 3. Aumento da intersubjetividade - o desenvolvimento da capacidade de reconhecimento do outro como sujeito histórico e a possibilidade do respeito mútuo no âmbito da aceitação das diversas identidades (RÜSEN, 2012).

No âmbito da investigação empírica, distinguir entre a assimilação de uma ampla gama de informações, a partir dos potenciais da linguagem fílmica, e o efetivo aumento das experiências históricas dos sujeitos, é um grande desafio devido às várias nuances que inibem a demarcação de uma linha divisória clara. Porém, essa distinção é fundamental. Na análise do material empírico produzido a partir da pesquisa no Grupo Focal, ficou claro o direcionamento do olhar dos jovens para três pontos específicos das obras fílmicas assistidas, o que possibilitou a percepção de uma relação complexa e conflituosa entre ideias prévias*, questões suscitadas pelos filmes e problemáticas levantadas no decorrer das discussões.

São as questões que intrigaram os jovens em suas ideias sobre 0 nazismo: 1. Qual a real dimensão do papel de Hitler na História do nazismo e houve algo positivo em sua trajetória? 2. O nazismo é apenas sinônimo

Optou-se por não trazer à tona o levantamento completo das ideias prévias dos jovens, devido às limitações deste texto. Esses dados serão ressaltados na medida em que se relacionarem às análises aqui realizadas. 
de maldade e crueldade? 3. Qual foi o papel dos cidadãos alemães comuns como agentes históricos do nazismo? Essas questões se destacaram e nasceram da articulação entre as ideias prévias dos sujeitos e o que assimilaram com os filmes.

Desde o início das discussões no GF, a complexificação dos argumentos dos jovens foi notável, revelando que assistir aos filmes foi um exercício que ampliou o arsenal de referências dos alunos. O protagonismo da figura de Hitler para o regime nazista foi o primeiro grande tema, a partir do qual se pode observar esse aumento das experiências. Para analisar esse ponto, é interessante partir das respostas dos jovens sobre o que foi mais marcante para eles após terem assistido ao filme " Triunfo da Vontade" (RIEFENSTAHL, 1935):

Joseph**: Manipulação e alienação, eu pude perceber que, naquelas reuniões que eles faziam lá, que aquelas pessoas, aqueles jovens, o que o Hitler falava lá parece que alienava, que manipulava os jovens, que as ideias dele mexiam com os jovens, que os jovens não sabem muito bem o que querem da vida, ele meio que manipulava a cabeça deles.

Sophia: Então, eu coloquei no meu aqui o lado organizado, Hitler tipo 'humanitário', mostrando assim é, quando ele chegava naquelas passeatas lá apertando a mão das pessoas, recebendo um buquê de flores, da mamãe com um bebê, e a idolatria, uma forma de idolatria mesmo que o povo tinha para ele, porque todo mundo "nossa!", mostrava o pessoal assim com um sorriso, então pra mim o objetivo do filme era mostrar que Hitler era, "nossa!", não tinha, colocando assim, defeitos assim.

As falas dos jovens revelam um conflito cognitivo. Duas personagens históricas se destacam no filme "O Triunfo da Vontade": Hitler e o povo alemão. Hitler, que inicialmente era tido como ditador cruel, passa a ser visto como um ídolo, um herói, um ícone histórico. Já o povo, que antes sequer era mencionado, agora é objeto de preocupação para os jovens, que tentam compreender que papel os alemães tiveram no nazismo. Veja-se trechos da discussão:

\footnotetext{
** Os nomes dos alunos são fictícios, a fim de preservar a identidade dos jovens. Tais nomes foram escolhidos por eles próprios.
} 
Mr. Roberto: Eu acho que a argumentação dele (Hitler) foi fundamental para influenciar o povo a seguir o seu regime de governo, por isso que eu coloquei que ele era inteligente, ele era "inteligentíssimo!", porque ele tinha uma argumentação muito boa, a argumentação dele convencia, a argumentação dele fazia com que os alemães sentissem um gosto assim de superioridade, então acho que a argumentação dele é "fantástica!".

Nélio: [...] uma grande revolução de Hitler para a Alemanha;

Moderador: Você acha que o Hitler estava transformando a Alemanha, o filme mostra isso para você?

Nélio: Acho que é isso.

Moderador: E essa transformação é para melhor ou para pior, quem tem alguma ideia?

Marcio: Seria uma ideia inovadora, tipo assim, todo mundo buscar o mesmo caminho.

As falas de Mr. Roberto, Nélio e Marcio deixam clara a ideia chave na compreensão do primeiro filme: a concepção do nazismo como um fenômeno histórico ímpar, que transformou a Alemanha a partir do protagonismo de Hitler, como grande líder das massas. Isso representou um aumento das experiências históricas, mas ainda vinculado a um reforço de padrões pré-concebidos. Mas essa mesma centralidade de Hitler, ainda no primeiro filme, também revelou novas dimensões do passado para os jovens:

Moderador: Esse filme trouxe alguma coisa de novo para vocês?

Sophia: Para mim trouxe, porque eu sempre achava que Hitler era uma pessoa mais dura, mais séria, e ali mostrou assim um lado mais bom né, nesse caso, parecia que as pessoas achavam ele mais intocável, mas ele mesmo ia e tocava nas pessoas.

Joseph: Eu concordo com ela porque eu também não pensava assim de Hitler, nos filmes que eu assisti não mostrava explícito isso, e no filme ali parece que o Hitler era uma pessoa mais humanista, mais próxima do povo, quer mostrar isso.

Katherine: Com o passar do tempo a sociedade foi julgando ele como vilão, a gente parando para analisar a gente percebe que a história tem dois lados, ele não é totalmente um vilão, não sei, não posso me colocar no lugar, mas a história tem dois lados, que no fundo não foi só o que aconteceu, mas tem algo por trás ali. 
As falas dos jovens explicitam o aumento das experiências no sentido da percepção de algo novo sobre o passado. No caso de Katherine, ela ainda deixou explícito um raciocínio que vincula essa nova experiência a um repensar da História num âmbito epistemológico, dando os primeiros indícios de um processo de ressignificação da História, não mais vista como um passado fixo e monoperspectivado.

Ao reconhecer o outro na História, no caso os alemães como agentes históricos, os jovens ampliaram seus próprios referenciais históricos, no sentido de tentar entender aquelas pessoas a partir de seus próprios pontos de vista, ou seja, ao enxergar a História como palco de atuação dos sujeitos, cada um em seu espaço e tempo. Abre-se, então, a possibilidade de dar novos significados à própria identidade, reconhecendo-se também como agente histórico:

Moderador: $O$ que seria esse algo por trás? (Além de um olhar negativo do nazismo)

Katherine: Foi um regime, a organização que trouxe, era um regime, não era bom, mas também não era ruim, olha a organização que eles tinham, o movimento que eles faziam. Mas, por outro lado também eles destruíam muitos e muitos países.

Mr. Roberto: Ele queria o melhor para o povo dele, o povo da Alemanha.

Sophia: É, a questão é que eles já tinham sofrido aquele negócio lá da Primeira Guerra, o povo estava um pouco mais fragilizado, daí aquilo serviu para animar mais eles, acho que até por isso ele teve mais poderes nessa persuasão que ele teve com as pessoas, ele fala assim a não, vocês são superiores, vocês não vão perder.

Mr. Roberto: Ele estava tentando levantar a Alemanha, porque a Alemanha já tinha passado pela Primeira Guerra Mundial, então a sociedade ela estava meio quebrada né!, então ele estava tentando reerguer a Alemanha, reestruturar a sociedade da Alemanha.

Não é simplesmente aceitar ou rejeitar o nazismo que está em questão, mas o debate surgido a partir do tensionamento das ideias prévias, quando os jovens passaram da simples ideia de assimilação do nazismo como símbolo de maldade, para sua compreensão como uma ideologia específica. Mesmo a figura de Hitler tendo se mantido em todas as discussões como central para se pensar o nazismo, desde o momento em que os jovens assistiram ao primeiro filme sua relação com essa experiência 
histórica foi qualificada a partir da entrada em cena do povo alemão como personagem importante dessa História. A percepção das intenções e ações dos sujeitos, diante daquele fenômeno histórico, pode ser considerada uma complexificação qualitativa importante na forma como tais jovens passaram a lidar com esse conhecimento.

Percebe-se, então, com a discussão suscitada a partir do primeiro filme, que os jovens estudantes passaram a duvidar de suas próprias ideias, as quais vinculavam o regime nazista à ideia simplista de crueldade e irracionalidade. Os projetos, valores e sentimentos envolvidos passaram a ser considerados como pontos de reflexão, sem com isso terem se deixado levar pela propaganda nazista implícita na obra fílmica.

Moderador: [Essa] história pode ter um olhar diferente, ser olhada de outro jeito, como algo bom?

Katherine: Eu acho que tudo bem, que o fato da organização, da união deles, tudo que eles fizeram, mas são todos fatos supérfluos perto do que foi o nazismo, de toda destruição, que nem você não tem como colocar na balança os dois valores, porque a parte do lado ruim prevalece sobre a parte do bom, eu acho que o lado bom do nazismo é muito fraco perto do que aconteceu.

Monique: Não justifica né! Claro né professor, porque imagina, quanto judeu morreu por causa dele, das ideias dele.

Laura: Porque o nazismo, os alemães lá eles gostavam muito do país deles, então eles acabavam prejudicando os outros países, que eles entravam em conflito; era bom só para eles, que viviam no nazismo;

Marcio: Então, eles tentaram fazer uma superação do que tinha acontecido, no caso na Primeira Guerra.

Os jovens tentaram ampliar os pontos de vista e perceber como o nazismo representou algo importante para os alemães da época, mas isso não anula a ideia de que aquela experiência chegou a resultados catastróficos. O reconhecimento da alteridade do passado é reforçado pela possibilidade de distinção entre nós, nesse caso os jovens no presente, e os outros, representados pelos alemães em suas práticas de aceitação do regime nazista. Ressalta-se, novamente, a noção central de que não é o filme em si que mobiliza uma aprendizagem histórica complexa por parte desses jovens, mas como a obra dialoga com as ideias prévias, e como os 
valores e sentimentos desses estudantes são mobilizados diante de situações que provoquem ideias conflitantes.

Quando os jovens lidam com uma fonte, como esse documentário alemão produzido em 1935, tal obra representa mais do que um acréscimo de informação histórica aos seus repertórios prévios, pois a consciência histórica consiste numa forma de se lidar com o passado a partir de como ele dá sentido ao mundo presente. Os jovens ampliaram seu arcabouço de referências históricas ao se colocarem diante do desafio de interpretar historicamente as narrativas fílmicas, incluindo sujeitos e situações anteriormente não imaginadas. As tentativas de qualificar historicamente e demarcar o perfil dos nazistas, como sujeitos de outro espaço/tempo que cometiam ações estranhas, foram uma tônica no processo de aprendizagem.

Num primeiro momento, os estudantes pensavam o nazismo a partir de um modelo esquemático, no qual a História se concebe como uma fórmula pronta, e as condições objetivas de crise e trauma teriam levado o povo a atitudes de barbárie e irracionalidade. A superação desse pensamento esquemático simplista por um pensamento mais complexo, mesmo que de certa forma ainda esquemático, o qual reconhece a subjetividade dos atores, ainda que desqualificados por uma diferença temporal na qual se pensa que os indivíduos de hoje são melhores que os de ontem, expressa uma forma relevante de aprendizagem histórica.

As ideias históricas dos jovens entraram em dialogo com o filme e eles reconstruíram suas ideias, sem abandonarem totalmente os argumentos preestabelecidos. A centralidade de Hitler como personagem histórica, que já fazia parte das preocupações desses jovens, foi reforçada pela própria natureza do filme assistido, visto que "O Triunfo da Vontade" foi efetivamente uma obra carregada de estratégias artísticas voltadas à valorização da imagem desta personagem. Os pontos assinalados como preponderantes no aumento das experiências dos jovens sobre o nazismo podem ser sintetizados em três temas relevantes: 1. O reforço da concepção de heroísmo, a partir da influência do líder sobre a população; 2. A preocupação com a real dimensão da participação coletiva nos processos 
decisórios; 3. A perspectivação do conceito de maldade a partir de sua contextualização na dimensão cultural e temporal.

Tabela 1 - Aumento das experiências a partir do filme "o triunfo da vontade"

\begin{tabular}{|c|c|c|}
\hline \multicolumn{3}{|c|}{ Filme "O Triunfo da Vontade" } \\
\hline $\begin{array}{l}\text { Ideias } \\
\text { prévias }\end{array}$ & $\begin{array}{c}\text { Reforço das } \\
\text { concepções prévias }\end{array}$ & $\begin{array}{l}\text { Aumento das } \\
\text { experiências }\end{array}$ \\
\hline $\begin{array}{c}\text { Trajetória } \\
\text { condenável e } \\
\text { protagonismo de } \\
\text { Hitler }\end{array}$ & $\begin{array}{c}\text { Grande capacidade de } \\
\text { liderar }\end{array}$ & $\begin{array}{c}\text { Um Hitler mais humano } \\
\text { Hitler foi bom para os alemães } \\
\text { Não era totalmente um vilão, a } \\
\text { história o julgou }\end{array}$ \\
\hline $\begin{array}{c}\text { Ausência do povo } \\
\text { alemão }\end{array}$ & Não houve & $\begin{array}{c}\text { Alienação, idolatria, ilusão } \\
\text { coletiva, sentimento de } \\
\text { superioridade, luta pela superação } \\
\text { das próprias fraquezas }\end{array}$ \\
\hline $\begin{array}{l}\text { Nazismo como } \\
\text { maldade }\end{array}$ & Não pode ser justificado & $\begin{array}{c}\text { Organização exemplar } \\
\text { Revolução para a Alemanha } \\
\text { Proximidade entre o líder e o povo }\end{array}$ \\
\hline
\end{tabular}

Fonte: "Estudo Final", Acervo do pesquisador (2014).

É possível afirmar que durante o estudo empírico houve uma qualificação da compreensão dos jovens sobre o nazismo, especialmente quando revelam uma preocupação com o envolvimento dos cidadãos comuns com a ideologia nazista. A questão que ficou em aberto no primeiro filme, e que se constituiu como uma primeira grande indagação para os jovens, foi saber se o apoio popular ao regime nazista era fruto de uma espécie de ilusão coletiva manipulada pela autoridade, ou se resultava dos sentimentos populares diante da situação vivida pelo país na época.

O debate surgiu a partir da já ressaltada relação entre aquilo que o filme trouxe de novo e o que os jovens já conheciam sobre o regime nazista. Essa relação entre Hitler e o povo se complexifica mais no debate após assistirem o segundo filme. Destacamos o fato de que esse filme, "A Queda! As últimas horas de Hitler", repercutiu internacionalmente por ter sido produzido a partir das memórias da secretária de Hitler, trazendo uma visão mais humana do Führer, assim como expressando o ponto de vista e a presença dos cidadãos alemães, de certa forma, como vítimas das circunstâncias causadas pela guerra. Nesse ponto, alguns aspectos relevantes chamaram a atenção dos estudantes: 
Moderador: Ficaram com dúvidas?

Anne: $O$ que o Hitler tinha na mão? [...] (Tremedeira da mão de Hitler chamou sua atenção) porque eu ficava assim: "O que ele está fazendo meu Deus?".

Moderador: Isso para você muda alguma coisa da imagem que você tinha do Hitler antes?

Anne: Ah... que ele não é tão intocável, sei lá... que ele também é humano e também pode pegar doenças.

O breve trecho acima retratado revela a preocupação da jovem Anne sobre como a imagem de Hitler como um ser humano frágil, doente e decrépito, muito presente no filme "A Queda!", traz uma nova visão da liderança de Hitler. A partir desse filme, ocorrem questionamentos ao protagonismo de Hitler na História do nazismo, enquanto o povo alemão ascende como personagem central dessa mesma História.

Moderador: Então a Katherine falou, e depois os outros concordaram, eu não sei se concordaram, que um filme complementa o outro. E eu queria perguntar, complementa ou traz algo a mais? Uma ideia diferente, uma compreensão diferente?

Joseph: Traz algo a mais, porque no primeiro filme mostra que o nazismo era algo ótimo, maravilhoso, daí nesse outro filme mostra mais a realidade, na visão da secretária dele, talvez não seja tudo verdade, mas na maioria das cenas a secretária viu, então acho que mostra o que ela viu realmente.

Mr. Roberto: Acho que naquele momento ali Hitler já começou a agir só por si mesmo, o poder subiu na cabeça dele e ele queria porque queria dominar o mundo de qualquer forma, e a partir dali ele já não pensava mais no povo, em querer uma Alemanha melhor.

Sophia: Ele estava direcionando muito mais para ele, não aquele povo... No começo era a ideia assim que ele passava, mas depois ele começou a dizer "Ai, porque eu tinha a Europa toda nas minhas mãos, agora não tenho mais nada, estou sendo traído".

Moderador: E como ela via o Hitler?

Fernanda: Eu acho que ela via ele como uma pessoa boa, não ruim, porque ela quis ficar do lado dele o tempo todo, até o fim da guerra, então eu acho que ela via ele como uma pessoa boa.

Mr. Roberto: É, como ela era alemã também não é. Daí foi mais pessoas, eles estavam alienados por ele não é.

Nesse momento, percebe-se como a possibilidade de interpelação das próprias ideias, a partir do que o filme trazia de novo, fez com que os 
jovens criassem questões novas e se tornou possível uma ampliação do arsenal argumentativo e reflexivo sobre a História. Pode-se, então, abordar a discussão sobre a recepção fílmica, na qual é consenso de que há uma seleção de conteúdos fílmicos a serem assimilados pelos espectadores, e que tal seleção depende de um repertório cultural (DAYAN, 2009). Fica claro como há uma relação estreita com as ideias históricas previamente manifestadas, mas há também um processo de aprendizagem no qual um novo filme e uma nova discussão ampliam os horizontes dessa aprendizagem.

O segundo filme trouxe à tona uma nova discussão, pensar Hitler como uma figura humana, com erros e acertos, e também repensar o papel dos cidadãos alemães em relação à manutenção do regime nazista.

Moderador: Se vocês fossem escolher uma cena, qual é a cena mais marcante?

Sophia: Para mim foi a cena em que ele falou assim que os civis também deviam morrer porque antes ele sempre valorizava o povo alemão, aí na hora em que teve aquele ataque histérico lá, ele falou assim "não, eles também têm que morrer, porque eles são fracos, porque eles estavam mostrando traição". Meio que ele fantasiava na cabeça dele, porque enquanto as pessoas estavam sofrendo, e ele ainda culpava eles.

Joseph: Eu também achei que é o que ela falou ali, que também ele idolatrava o povo, que nem, a raça alemã que eles diziam, e no final ele dizia que eles tinham que morrer, ficou contraditório com o que eu achava antes.

Moderador: Por que ele achava que o povo tinha que morrer?

Anne: Porque na cabeça do Hitler achava que o povo não estava sendo fiel.

Laura: O que chamou a atenção foi a morte de Hitler mesmo, dele ter se matado. Porque ele era tão poderoso, e acabar tendo que se matar [...]. Porque ele foi fraco, viu que estava perdendo lá e não quis continuar mais.

Sophia: Onde o orgulho leva a pessoa não é, porque ele preferiu se matar do que se render, e ainda fez a cabeça dos outros falando não, não vamos nos render.

Moderador: Vocês viram que em um momento ele disse "vocês façam o que quiserem", e mesmo assim muitas pessoas continuaram esperando a opinião dele. Por que será? Anne: Idolatria.

Laura: As pessoas achavam que ele era o líder, no começo as tropas eram tudo organizadas, todo mundo lá, depois que estavam perdendo ele falou ah, não quero mais. 
Mr. Roberto: As pessoas tinham fé nele, era só um momento que ele estava passando por aquela crise, mas acreditavam que ele iria dar a volta por cima.

Se nas discussões após o filme "O Triunfo da Vontade" a tendência foi aceitar a ideia de que os líderes nazistas, especialmente Hitler, manipulavam os cidadãos e os iludiam, fazendo-os cair na "armadilha" do nazismo, a partir da discussão sobre o segundo filme, já se nota uma relativização dessa concepção, e a noção de que havia certa reciprocidade entre os líderes e o povo.

Tabela 2 - Aumento das experiências a partir do filme "a queda!"

Filme "A Queda!"

\begin{tabular}{l|c|l}
\hline Ideias prévias & $\begin{array}{c}\text { Reforço das } \\
\text { Concepções }\end{array}$ & \multicolumn{1}{c}{ Aumento das experiências } \\
\hline $\begin{array}{l}\text { Trajetória } \\
\text { condenável e } \\
\text { protagonismo de } \\
\text { Hitler }\end{array}$ & $\begin{array}{l}\text { Fragilidade e decrepitude } \\
\text { Sofreu com a decadência do regime } \\
\text { cabeça à }\end{array}$ & $\begin{array}{l}\text { Foi fraco ao se suicidar } \\
\text { Culpou os alemães pela derrota } \\
\text { Traiu suas conviç̧ões sobre a } \\
\text { superioridade alemã } \\
\text { Se mostrou orgulhoso }\end{array}$ \\
\hline $\begin{array}{l}\text { Ausência do povo } \\
\text { alemão }\end{array}$ & Não houve & $\begin{array}{l}\text { Admiração da secretária por Hitler } \\
\text { Traídos pelo líder } \\
\text { Mesmo traídos, confiaram até o fim } \\
\text { Devoção por Hitler } \\
\text { Confiança nos ideais nazistas }\end{array}$ \\
\hline $\begin{array}{l}\text { Nazismo como } \\
\text { maldade }\end{array}$ & Não houve & \begin{tabular}{l} 
Experiência de sofrimento \\
\hline
\end{tabular}
\end{tabular}

Fonte: "Estudo Final", Acervo do pesquisador (2014).

A retomada dos três temas anteriormente destacados, como é possível observar na tabela acima, revela que há um aumento das experiências por parte dos sujeitos da pesquisa. Enquanto, anteriormente, Hitler havia sido visto como uma liderança admirável, no segundo momento houve um descrédito para com a sua figura, retomando o padrão de maldade com o qual sua trajetória era identificada. Mas, agora, com uma sofisticação dos argumentos e das considerações, especialmente pela concepção de que "o poder subiu à cabeça".

O entendimento do protagonismo de Hitler como personagem histórica do nazismo foi mantido intacto. Contudo, sua identificação como 
ícone de maldade foi relativizada, primeiramente com a contraposição a essa ideia, a partir do primeiro filme, em seguida, a partir do segundo filme, com a retomada dessa ideia a partir de uma justificativa histórica: as pressões da guerra, a derrota e o descontrole com o excesso de poder, teriam levado Hitler a demonstrar fraqueza, tomando decisões contraditórias e traindo seu povo, ou seja, a maldade não é mais vista como natural da personalidade de Hitler, mas como resultado de uma história de pressões e derrotas.

Outra mudança de padrão importante foi a ideia de que o nazismo não era só maldade. No primeiro filme, os jovens ressaltaram a concepção de que o regime tinha um conjunto de valores partilhados pela comunidade, e que era um exemplo de organização política. E, no segundo, essa mudança de padrão se reforçou com a noção de que os nazistas também sofreram com a guerra e foram vitimados pela História.

Por fim, a constatação da presença do povo alemão na História expressa uma compreensão histórica importante. Se nas ideias prévias ela sequer era mencionada, no primeiro filme os alemães foram entendidos como sujeitos dominados ou iludidos pela ideologia dominante. Contudo, após o segundo filme, os jovens passaram a considerar a possibilidade de 0 povo alemão ter sido agente importante dessa História, pois partilhavam os valores da ideologia e sustentaram até o fim o poder do líder.

Dessa forma, é possível retomar a análise dos três temas que direcionam a leitura que os jovens fizeram sobre os filmes: 1. Heroísmo Ações de Hitler continuam sendo decisivas; 2. Participação coletiva - o povo alemão garantia a manutenção do regime; 3 . Conceito de maldade - pode ser entendido pelas vias da reação ao sofrimento e da crença em valores e ideais próprios. Esses temas revelam operações complexas da consciência histórica, e podem ajudar, a partir de outros estudos mais aprofundados, a pensar na forma como os jovens se relacionam com a História e constroem padrões de interpretação histórica.

O terceiro filme assistido e debatido foi "O Pianista". Trata-se de uma obra com grande repercussão internacional, que retrata a saga de um pianista judeu-polonês tentando sobreviver durante a ocupação de Varsóvia 
pelas tropas nazistas na Segunda Guerra Mundial. A compreensão manifestada pelos jovens a partir do debate sobre esse filme não apresentou elementos que pudéssemos qualificar como "aumento das experiências" em relação ao nazismo, pois grande parte da obra reitera a noção de irracionalidade e crueldade da ideologia nazista, que se manifesta no filme devido ao fato de ser uma obra baseada nas memórias de um perseguido.

Entretanto, um aspecto dessa obra chamou a atenção dos jovens e foi tema central dos debates. Trata-se do fato de que a personagem principal do filme foi salva por um oficial alemão, o que provocou certa incompreensão inicial, mas levou a raciocínios complexos e interessantes, que foram analisados a partir do conceito de Empatia Histórica, tema do próximo tópico deste artigo.

\section{Compreensão e Empatia Histórica: limites e possibilidades}

No Grupo Focal, três pontos nortearam a discussão a partir do primeiro filme: o reforço do heroísmo na figura de Hitler e certa inclinação a relativizar a memória negativa que se construiu em torno do nazismo; a incorporação do povo alemão como sujeito histórico relevante para a História nazista; e também o questionamento da concepção estreita de maldade pura em relação ao nazismo. Esse último ponto pode ser ainda melhor compreendido a partir da análise dos trechos a seguir:

Moderador: [...] eu queria propor uma ideia aqui, a Sophia disse que o Hitler aparece como bom para os alemães, e o Joseph colocou que o povo estava sendo iludido. Vocês conseguem pensar no que seria ser um alemão na época e viver nesse governo? O filme ("O Triunfo da Vontade") ajuda a pensar nisso ou só nesse outro lado, das pessoas serem enganadas e manipuladas? Será que as pessoas acreditavam naquilo ou não, o que vocês acham?

Monique: Eles tinham uma devoção por Hitler, eles achavam que aquilo que era certo, não é?

Sophia: Isso também até já dá para, pensando por esse lado, no ego das pessoas. Porque falavam que os alemães eram uma raça superior, então no caso para mim eles 
acreditavam assim que eles eram diferentes dos demais, superiores aos outros.

É interessante observar como os jovens se esforçam para qualificar a interpretação de que houve algo a mais além da maldade pura e simples na História do nazismo. As falas mostram um conflito: a jovem Monique continua destacando a ação de Hitler como determinante para os alemães. Mas a jovem Sophia, por outro lado, mostra uma nova compreensão, segundo a qual o nazismo não foi apenas uma ideologia implantada na mente das pessoas por uma espécie de ilusão coletiva. Ademais, vislumbra a possibilidade de os valores nazistas serem partilhados pelos alemães por representarem um sinal de distinção, de elevação da autoestima, como ela mesma disse, pensando "no ego das pessoas".

$O$ processo de aprendizagem a partir dos dois primeiros filmes definiu-se, então, por um aumento inicial da experiência, quando a visão tradicional e negativa que tinham do nazismo foi confrontada por obras que Ihes mostravam o outro lado da questão. Também tentaram reconhecer 0 papel dos alemães, possibilitando o surgimento de novas ideias, dentre as quais destacaram a desmistificação da figura de Hitler e o incômodo com a colaboração dos cidadãos comuns para com o regime nazista.

Nesse ponto, podemos construir nossas análises a partir do conceito de Empatia Histórica. Isto porque, para além das concepções individuais e das certezas que cada um constrói sobre o passado, há outros passados possíveis, representados pelas experiências, vivências e percepções de outros sujeitos em seus espaços e tempos específicos. Os potenciais da linguagem fílmica dinamizaram essa relação de forma complexa, levando os jovens a lidarem com o exercício da empatia histórica e colocando pontos de análise relevantes.

O conceito de empatia histórica é central no âmbito da cognição histórica situada, pois se refere à possibilidade de os jovens desenvolverem uma relação complexa com os sujeitos do passado, visto que se trata de um exercício de compreensão das ações e intenções dos indivíduos em seus próprios contextos históricos, reconhecendo a historicidade de seus atos, e 
não julgando ou qualificando suas decisões a partir dos referenciais do presente (LEE, 2003).

\begin{abstract}
Os alunos, tal como os historiadores, precisam compreender por que motivo as pessoas actuaram no passado de uma determinada forma e o que pensaram sobre a forma como o fizeram, mesmo que não entendam isto tão bem quanto os historiadores. A possibilidade directa de os alunos não compreenderem o passado é que este se torna numa espécie de casa de gente desconhecida a fazer coisas ininteligíveis, ou então numa casa com pessoas exatamente como nós mas absurdamente tontas. (LEE, 2003, p. 19)
\end{abstract}

A empatia exige a capacidade não só de ver os outros, mas também de se deslocar para o lugar do outro. E, dessa forma, mais do que tentar compreender os feitos, refere-se também a tentar compreender finalidades, contextos e atuações. É uma forma de qualificar a compreensão do passado, superando as formas comuns de interpretação, que utilizam o presente como ponto de partida e referência. Em contraponto, a incompreensão da motivação das pessoas no passado leva a um estranhamento, que também pode levar à minimização de sua importância.

Nas discussões no Grupo Focal, por diversas vezes, o exercício da empatia histórica foi exigido dos jovens, para que pudessem desenvolver uma compreensão mais complexa dos feitos dos agentes históricos. Nesse âmbito, o trecho a seguir pode ser destacado:

Moderador: As pessoas marchando, as multidões, que impressão essas imagens deixaram para vocês?

Sophia: A impressão é de um ultranacionalismo, que as pessoas idolatravam o país deles.

Katherine: Eles estavam ali para defender a pátria deles, eles acreditavam porque Hitler dizia que eles eram superiores, eles faziam isso porque eles tinham fé que eles iam ser os melhores, que eles não iam sofrer tanto como eles sofreram no passado, que tempos bons iam vir;

Mr. Roberto: Eles acreditavam nas propostas de Hitler né, como eu disse, a argumentação dele era muito boa então por isso o povo acreditava nele.

Na discussão sobre o primeiro filme, já era possível analisar como os jovens ampliaram suas concepções. Da noção inicial prévia segundo a qual o nazismo era uma doutrina irracional, passaram a observar os motivos que 
levaram os sujeitos a aderir ao projeto do nacional-socialismo. Expressões como: "idolatravam o país deles", "tinham fé que eles iam ser os melhores", "acreditavam nas propostas de Hitler", já denotam essa concepção segundo a qual os jovens tentam entender as ações dos sujeitos do passado sem julgá-las ou menosprezá-las, sem tratá-las como irracionais ou incompreensíveis. As promessas de glória do nazismo e o sentimento de unidade, expressos no primeiro filme, levaram os jovens a mobilizar a empatia histórica. Esse processo se tornou ainda mais acentuado com o andamento das discussões:

Moderador: Afinal, o nazismo era bom ou ruim para os alemães?

Anne: Para os alemães era bom.

Joseph: Eu acredito que na época era bom, porque eles protegiam os alemães.

Katherine: Antes de 42 era bom.

Monique: Eu acho que sim (era bom), mas eles não pensaram no que podia acontecer depois.

Os jovens se colocaram no lugar dos alemães, entendendo o nazismo como algo bom para aquelas pessoas, e ainda fizeram considerações corretas sobre esse ponto de vista, a partir da perspectiva da mudança. A jovem Katherine assinalou o ano de 1942, antes da derrocada da Alemanha na Segunda Guerra Mundial, para justificar sua afirmativa, enquanto a jovem Monique tornou ainda mais complexo o exercício de empatia, pois considerou o fato dos alemães não terem consciência do rumo que as coisas tomariam.

Essa discussão se tornou mais complexa a partir do debate sobre o filme "O Pianista". A análise sobre a forma como o pianista foi ajudado por um comandante nazista deixou clara a complexidade da compreensão a partir da empatia histórica.

Moderador: Que dúvidas surgiram com esse terceiro filme? Marcio: No final eu não entendi porque o policial ajudou ele. Moderador: É uma boa questão, porque ele foi ajudado por um nazista? A gente pode começar com essa questão.

Laura: Porque ele era um bom pianista.

Moderador: Concordam? 
Sophia: É, quando ele tocou meio que comoveu ele, também não sei, depois de tantas mortes não é, vai ver ele quis poupar uma.

Katherine: $O$ único que restou ali.

Sophia: Para mim, eu achei assim, que pelo talento dele, eu acho que o nazista assim meio que não levou tanto em conta o fato dele ser judeu, porque ele viu que o talento dele, porque nossa aquela peça que ele toca é muito linda não é, porque o talento dele, o fato dele ser pianista, era mais relevante do que ele ser judeu e ser mais um que ele ia matar.

Joseph: Eu não acho que é só porque ele era pianista. Porque a gente fala que todos eram maus, mas uma hipótese assim que nem todos deviam ser, que eles lá eram generais, mas como estava no fim da guerra, talvez ele pensou em deixar ele viver, não queria mais matar. Poderia ser uma pessoa diferente, a gente não pode generalizar que todos os alemães eram maus.

Katherine: Talvez o rapaz até fosse contra, mas de repente por falta de opção ele teve que se render e virar soldado do nazismo, talvez a força dele não fosse matar tanta gente, por isso uma boa motivação dele salvar o pianista.

Esse debate foi sendo direcionado, no jogo de perguntas e respostas entre o moderador e os jovens estudantes, para a novidade que o filme trazia, que gerou um conflito de concepções e uma maior sofisticação da experiência histórica. A partir da dúvida despertada no jovem Marcio, sobre como foi possível um alemão ajudar um judeu fugitivo, o debate derivou para um processo de crescimento da subjetividade na relação com a experiência histórica.

Por mais que o filme tenha sido elaborado com o propósito de resgatar a experiência de sofrimento da sua personagem central, um judeu fugindo do regime nazista, ele possibilitou um olhar mais complexo sobre os próprios nazistas por parte dos estudantes. Eles passaram a questionar a própria concepção, que classificava os sujeitos históricos a partir de tipos esquemáticos, como os alemães, os judeus. A ideia de que "nem todos os alemães eram maus", depois contrabalançada pela concepção de que nem todos os judeus foram vítimas, possibilitou um complexo processo interpretativo por parte dos estudantes, que passaram a requalificar a concepção que tinham da experiência histórica estudada.

O que levou um oficial nazista a salvar um judeu? Teria sido o apreço do oficial pela música? A jovem Sophia, que é uma musicista, levantou essa 
hipótese, a qual não deixa de ser plausível. Essa foi uma das possibilidades que o filme, baseado nas memórias do pianista, deixou subentendidas. "Nem todos os alemães eram maus", essa concepção, levantada por Joseph, que revela um raciocínio histórico sofisticado, é complementada por outro raciocínio, de que a proximidade do fim da guerra teria levado o oficial a algum tipo de exaustão, ou de resistência à brutalidade da guerra que promovia.

A inferência feita pela jovem Katherine situa-se em outro aspecto, na constatação que o nazismo não era uma unanimidade na Alemanha e que, possivelmente, o oficial estivesse na guerra sem uma convicção dos ideais nacional-socialistas. Por isso, salvar um pianista judeu seria algum tipo de exercício de benevolência, uma espécie de compensação moral. Nenhuma das hipóteses levantadas pelos jovens deixa de ser plausível. A ausência de evidências pontuais para justificar determinadas interpretações leva os jovens a realizarem leituras complexas, mobilizando os conhecimentos sobre o nazismo e buscando alternativas de entendimento da ação do oficial nazista em outras referências históricas.

Mas esse potencial de análise e compreensão do passado não se manifesta o tempo todo. Em alguns casos, os jovens demonstraram dificuldades em exercitar a empatia histórica, como em algumas cenas do filme, o que pode ser visto no exemplo a seguir:

Mr. Roberto: Aquela cena também que aqueles jovens lá estavam lutando na guerra lá e receberam medalhas do Hitler. O filme ("A Queda!") mostrou que desde cedo os jovens já eram incentivados a ir para a guerra. E eles estavam levando aquilo como uma diversão assim, eles estavam gostando e tal, teve aquela cena que o 'piazinho' falou que destruiu dois tanques com uma bazuca. "nossa!" (risos).

Sophia: Aquilo lá é bem contraditório, com o mundo caindo ao redor e eles lá recebendo medalhas.

O estranhamento em relação às tomadas de decisões dos sujeitos do passado é um desafio para a empatia histórica, especialmente quando se tratam de valores muito distintos daqueles que os jovens estão acostumados. A situação dos alemães no final da guerra, a esperança da vitória, o orgulho de servir ao líder, tudo isso pareceu incompreensível aos 
olhos dos jovens. Mas há aí um problema comum, limitador do pensamento histórico, que se trata do anacronismo. Ao não compreenderem a ação daqueles soldados alemães, também deixaram de levar em consideração que eles não sabiam que a Alemanha perderia a guerra e, mesmo se soubessem, eles tinham toda uma bagagem cultural e emocional que os ligava aos valores militares, como a honra de defender o país e o orgulho de ser reconhecido por isso.

Esses estranhamentos, ou as complexidades no desenvolvimento da empatia histórica, ficam ainda mais evidentes quando se questionou, ao final do terceiro debate, sobre o extermínio dos judeus pelos nazistas. Esse ponto gerou um debate a partir do exercício da empatia histórica:

Moderador: Em algum momento a Monique falou que os judeus não morreram sem sentido. E a minha pergunta é: tinha um sentido?

Jospeph: Depende, para os alemães tinha um sentido, que era exterminar por que os alemães culpavam eles pelo fracasso da Alemanha depois da guerra.

Katherine: Do lado do nazismo tinha, que era criar a raça pura.

Moderador: Monique, você acredita no sentido daquilo que os alemães faziam ou apenas entende que para eles aquilo tinha sentido, mas você não acredita?

Monique: Eles acreditavam, eu hoje não iria acreditar. Imagina matar todo mundo porque quer criar uma raça pura.

Moderador: $E$ por que é importante entender que para eles aquilo tinha um sentido?

Monique: Se eles não acreditassem eles não teriam matado todo mundo igual eles mataram, agora sei lá, para eles tinha um sentido não só tipo criar uma raça pura, ou porque eles tinham fracassado, a Alemanha, não só por isso, porque senão eles atacavam outros países não é, teria mais sentido, mas também porque eles não queriam que uma raça melhor do que a deles, eu acho que é isso.

Diante de um fato de difícil compreensão para esses jovens, o extermínio de um povo considerado inimigo ou inferior, eles mobilizaram a empatia histórica como forma de dar sentido ao passado. Percebe-se, então, que esse exercício permite uma compreensão maior do passado, mas não inibe raciocínios elaborados a partir de formulações préconcebidas, que pensam os sujeitos do passado como inferiores, ou 
determinados por padrões de comportamento enquadrados em esquemas simplistas. Como no exemplo a seguir:

Pesquisador Assistente: Só para completar a ideia, várias pessoas falaram sobre liderança, e o moderador falou assim para vocês: imagina que vocês estão em casa, vendo televisão e passe alguma coisa, e a pessoa que está com você não sabe nada sobre o nazismo, como é que você contaria, o que você falaria para a pessoa? Vocês acham que, hoje, o Brasil precisa mudar as coisas, não precisa? Não só no Brasil, no mundo inteiro as coisas precisam mudar. Se existisse uma liderança, vocês acham que as pessoas seguiriam essa liderança e essas coisas poderiam mudar? Você acha que o que falta hoje é um líder?

Monique: Não.

Franklyn: Não. Hoje tem muito pensamento diferente, então não daria muito certo.

Marcio: Isso! Faltaria um líder para vários pensamentos diferentes. Então, seria o que um ia pensar e não iria abranger todos os pensamentos de todas as pessoas.

Pesquisador Assistente: E na época do nazismo, será que tinha vários pensamentos diferentes, ou não?

Fernanda: Por mais que tivesse, eles não colocavam exposto o que eles pensavam, o que eles sentiam. Então eu acho que era uma forma mais fácil de comandar eles. Hoje não, se você tem uma ideia, se quer lutar por aquilo, você vai e, por mais que você não consiga, você tenta, você coloca sua ideia em prática, por outras pessoas que tem a mesma ideia. Às vezes a pessoa consegue. O Hitler era um líder, ele queria acabar com os Judeus, ele não conseguiu e acabou desabando o império dele. Agora no mundo de hoje alguns tentam, mas as pessoas estragam, pelo fato de que, nas manifestações as pessoas tentam ver o lado bom, fazer alguma coisa boa, sempre vai ter uma ou duas pessoas que vai prejudicar eles, que vai fazer de uma forma errada, vai se aproveitar daquilo.

No caso dessa discussão, o que se percebe é a tendência em se comparar as pessoas do passado com as pessoas de hoje. Nessa mobilização de ideias, fica subentendido uma noção segundo a qual os sujeitos do presente são mais ativos, mais diversificados e mais resistentes a um único padrão de pensamento. Por mais que isso pareça um raciocínio lógico, é apenas uma visão superficial. Em diversos momentos, durante o segundo e o terceiro filmes, ficaram evidentes divergências no interior do nazismo que os jovens muitas vezes não conseguiram assimilar, pois esperavam um comportamento padrão das pessoas do passado. 
Apesar da percepção de mudança, especialmente da diferença entre os alemães, que viviam num regime autoritário, e os brasileiros hoje, num regime democrático, os jovens tendem a compreendê-la a partir de um padrão que identifica os sujeitos do passado como menos evoluídos, menos aptos à democracia. O autoritarismo, ou a liderança, não funcionariam porque eles entendem que a sociedade evoluiu no sentido de uma maior complexidade de atores sociais. Paradoxalmente, isso é reprovado por eles, que denunciam essa diversidade como um problema.

Há um duplo problema na análise dos jovens. O primeiro é julgar as pessoas do passado como inferiores ou menos evoluídas. O segundo é a visão negativa que eles têm da diversidade, o que tem grande implicação na forma como mobilizam a aprendizagem histórica. Essa complexidade do pensamento histórico dos jovens conduz à formulação, já presente nos pressupostos de teóricos da Educação Histórica, de que não há uma linearidade no processo de aprendizagem histórica.

É possível analisar a mobilidade nas formas de compreensão dos jovens a partir do conceito de Empatia Histórica com base no modelo elaborado por Peter Lee (2003). Esse modelo é uma ferramenta de análise do pensamento mobilizado pelos jovens, mas não consiste no estabelecimento de níveis fixos de progressão da aprendizagem. A tabela formulada a partir do "modelo de progressão em empatia histórica" permite categorizar ideias históricas mobilizadas no exercício de compreensão histórica. Definindo dos níveis mais simples aos mais sofisticados, elucida as lógicas utilizadas para explicar as ações dos sujeitos do passado: 1.Ausência de explicação; 2.Confusão, ou falta de sentido; 3.Explicação deficitária; 4.Explicação por estereótipos ou papéis pré-definidos; 5.Explicação em termos da lógica da situação; 6.Empatia histórica: ou explicação em termos do que as pessoas naquele tempo pensavam; e 7.Explicação em termos de um contexto material e de ideias mais amplo. 


\section{Tabela 3 - Categorização das ideias históricas mobilizadas pelos jovens a partir do modelo de progressão em empatia histórica}

\begin{tabular}{|c|c|c|}
\hline Questão le & Nível de compreensão & Ideias mobilizadas \\
\hline \multirow[b]{2}{*}{$\begin{array}{l}\text { As pessoas comuns } \\
\text { foram manipuladas } \\
\text { pelos nazistas? }\end{array}$} & Nível 4 - Estereótipos & $\begin{array}{l}\text { Eles tinham uma devoção por } \\
\text { Hitler }\end{array}$ \\
\hline & $\begin{array}{l}\text { Nível } 5 \text { - Lógica da } \\
\text { situação }\end{array}$ & $\begin{array}{l}\text { Os nazistas alimentavam o ego } \\
\text { das pessoas. } \\
\text { Havia um medo de se opor ao } \\
\text { regime }\end{array}$ \\
\hline \multirow[b]{2}{*}{$\begin{array}{l}\text { O primeiro filme mostra } \\
\text { as multidões apoiando } \\
\text { o nazismo, o que isso } \\
\text { faz pensar? }\end{array}$} & Nível 4 - Estereótipos & Ultranacionalismo \\
\hline & $\begin{array}{l}\text { Nível } 5 \text { - Lógica da } \\
\text { situação }\end{array}$ & $\begin{array}{l}\text { Fé na redenção e na superação } \\
\text { da humilhação sofrida } \\
\text { Acreditavam nas propostas de } \\
\text { Hitler }\end{array}$ \\
\hline \multirow{3}{*}{$\begin{array}{l}\text { O nazismo era bom ou } \\
\text { ruim para os alemães? }\end{array}$} & $\begin{array}{l}\text { Nível } 5 \text { - Lógica da } \\
\text { situação }\end{array}$ & $\begin{array}{l}\text { Bom porque protegia os } \\
\text { alemães }\end{array}$ \\
\hline & $\begin{array}{lll}\text { Nível } 6 & - & \text { Empatia } \\
\text { histórica } & & \\
\end{array}$ & $\begin{array}{l}\text { Não pensaram no que poderia } \\
\text { acontecer }\end{array}$ \\
\hline & $\begin{array}{l}\text { Nível } 7 \text { - Contexto mais } \\
\text { amplo }\end{array}$ & Antes de 1942 era bom \\
\hline \multirow{3}{*}{$\begin{array}{llr}\text { Por que } & \text { um oficial } \\
\text { nazista } & \text { salvou } & 0 \\
\text { pianista? } & & \end{array}$} & $\begin{array}{l}\text { Nível } 5 \text { - Lógica da } \\
\text { situação }\end{array}$ & $\begin{array}{l}\text { Era um bom pianista } \\
\text { O oficial quis poupar uma vida } \\
\text { no final da Guerra }\end{array}$ \\
\hline & $\begin{array}{l}\text { Nível } 6-\text { Empatia } \\
\text { histórica }\end{array}$ & $\begin{array}{l}\text { Talvez tenha se tornado oficial } \\
\text { nazista por obrigação, não } \\
\text { conviç̧ão }\end{array}$ \\
\hline & $\begin{array}{l}\text { Nível } 7 \text { - Contexto mais } \\
\text { amplo }\end{array}$ & $\begin{array}{l}\text { Nem todos os alemães eram } \\
\text { maus }\end{array}$ \\
\hline \multirow{2}{*}{$\begin{array}{l}\text { Por que Hitler dava } \\
\text { medalhas aos jovens } \\
\text { em meio à Guerra? }\end{array}$} & Nível 4 - Estereótipo & $\begin{array}{l}\text { As crianças se divertiam com a } \\
\text { guerra }\end{array}$ \\
\hline & Nível 2 - Confusão & Aquilo é bem contraditório \\
\hline \multirow{2}{*}{$\begin{array}{l}\text { Havia sentido na morte } \\
\text { dos judeus? }\end{array}$} & Nível 4 - Estereótipos & $\begin{array}{l}\text { Queriam criar a ra } \\
\text { judeus eram um o }\end{array}$ \\
\hline & $\begin{array}{l}\text { Nível } 7 \text { - Contexto mais } \\
\text { amplo }\end{array}$ & $\begin{array}{l}\text { Os judeus foram culpados pelo } \\
\text { fracasso da Alemanha na } \\
\text { guerra }\end{array}$ \\
\hline $\begin{array}{l}\text { Falta hoje uma } \\
\text { liderança como nos } \\
\text { tempos do nazismo? }\end{array}$ & $\begin{array}{l}\text { Nível } 3-\text { Explicação } \\
\text { deficitária (no passado } \\
\text { não tinham o que temos } \\
\text { hoje, "não eram tão } \\
\text { espertos".) }\end{array}$ & $\begin{array}{l}\text { Hoje não daria certo porque } \\
\text { tem muitos pensamentos } \\
\text { diferentes } \\
\text { Naquela época as pessoas } \\
\text { tinham medo de se expor, não } \\
\text { lutavam por seus direitos } \\
\text { Hoje não se faz um líder como } \\
\text { naquela época, as pessoas não } \\
\text { são tão unidas }\end{array}$ \\
\hline
\end{tabular}


As questões surgidas no debate direcionaram para esse exercício da empatia histórica, e a análise das respostas permite observar como a maior parte dos jovens se situou em um patamar intermediário de compreensão, entre os níveis 4 e 5 do modelo proposto por Lee. Mas, pensando em termos da noção de aumento das experiências, pode-se observar em que momentos os desvios puderam revelar algo além dessa constatação inicial.

O nível 2, de confusão ou incompreensão, se manifestou apenas uma vez, e se relacionou à situação inusitada, ou inesperada, dos jovens recebendo medalhas de Hitler em meio à guerra. Essa referência, de um comportamento inesperado dos jovens nazistas diante do extremo da guerra quase perdida, gerou um conflito cognitivo e ausência de uma explicação para a situação relatada. Já o nível 7 se manifestou duas vezes e, em ambos os casos, os jovens remeteram-se a conhecimentos históricos mais sofisticados, relacionados a contextos históricos mais amplos: traumas da Primeira Guerra e a culpabilização dos judeus; decadência do nazismo a partir de 1942, quando começou a perder a Segunda Guerra.

Esses desvios são interessantes porque se torna possível relacionálos ao arcabouço das memórias históricas dos jovens em questão, ou seja, às suas protonarrativas. A sofisticação das ideias dos jovens não dependeu apenas das fontes com as quais lidaram, mas também da forma com que as questões apresentadas se relacionavam a conhecimentos prévios. Isso fica mais evidente quando os jovens explicam as situações em termos de estereótipos, e muitos desses estão presentes na cultura histórica: devoção por Hitler, ultranacionalismo, ideal da raça pura, foram alguns dos estereótipos a partir dos quais as ações ou comportamentos dos alemães no nazismo foram entendidos.

Apenas uma vez um estereótipo não vinculado aos conhecimentos prévios sobre o nazismo foi mencionado, justamente na questão que tratava das crianças recebendo medalhas de Hitler: o jovem em questão usou o estereótipo que vincula o comportamento das crianças à noção de lúdico, e para ele isso explicaria o fato delas estarem felizes por receberem medalhas, pois a guerra teria se tornado uma brincadeira para elas. Essa compreensão a partir de estereótipos, para Lee (2006), revela uma 
compreensão histórica limitada, pois as ações dos sujeitos do passado são explicadas a partir do que se espera delas com base em noções superficiais que as vinculam a papéis e padrões de comportamento, e não por se levar em consideração a amplitude de situações e pontos de vista exigidos pela situação.

O importante, nesse ponto, é ressaltar como há uma preponderância da relação entre as protonarrativas dos jovens e a compreensão histórica elaborada. Dessa forma, a questão de que a aprendizagem histórica consiste num aumento de experiências não depende exclusivamente do que o filme mostra, mas também da forma como o conteúdo da obra fílmica mobiliza a consciência histórica dos sujeitos na aprendizagem histórica.

A complexidade de se analisar o pensamento histórico dos jovens fica clara a partir da fala da jovem Monique, assinalada no último trecho dos debates, uma vez que ela compreende que, para os Alemães, havia um sentido no extermínio dos judeus, mesmo considerando que, do seu ponto de vista pessoal, essa atitude é reprovável. Ela reprovaria a atitude hoje, mas não a condena no passado, porque ela foi justificada pelas condições daquele tempo, quando as pessoas tomaram tais decisões guiadas por sentimentos próprios. Essa forma de raciocínio é complexa do ponto de vista do pensamento histórico, mesmo se fundamentando no exercício da empatia. A questão da multiperspectividade fica prejudicada, uma vez que as vítimas do nazismo são desconsideradas numa análise fria, negando-lhes o papel de agentes históricos.

Nota-se, assim, a convicção dos jovens de que há "dois lados": os nazistas contra os judeus. Na fala de Katherine, isso ficou claro quando ela respondeu se havia um sentido no extermínio dos judeus, e a resposta foi: "Do lado do nazismo tinha". Ao invés de perceber os filmes assistidos como obras que revelariam distintas perspectivas, a tendência dos jovens foi pensar que há dois lados, uma dicotomia. Essa forma de compreensão limita a assimilação da categoria multiperspectividade. Essa dificuldade em se atingir um pensamento histórico que toma por base a multiperspectividade é um desafio ainda aberto nas pesquisas sobre cognição histórica situada. 


\section{Considerações Finais}

No presente texto, tomamos os filmes como fontes para o Ensino de História, e problematizamos a compreensão dos jovens sobre essas obras, tomando como referência o conceito de cognição histórica situada. Apesar de compreender que a linguagem fílmica, em si, pode ser compreendida como aspecto relevante nesse processo, optamos por destacar apenas os elementos relacionados a operações processuais do pensamento histórico, deixando em segundo plano a questão da recepção fílmica. Isso não significa que ignoramos esses aspectos, apenas que essa exclusão deliberada se justifica em função do objeto de investigação do presente estudo.

Nesse sentido, a busca foi por ressaltar duas importantes constatações da pesquisa desenvolvida: 1. A aprendizagem histórica a partir dos filmes não se faz de forma direta, pois é interpelada pelos fatores subjetivos referentes à cultura histórica partilhada e à mobilização das protonarrativas da consciência histórica dos sujeitos; 2. Aprender História é um exercício de cognição complexo, que consiste no aumento das experiências históricas, e não simplesmente na assimilação das mensagens contidas numa narrativa.

As duas constatações, acima definidas, são referências básicas para o campo da Educação Histórica, uma vez que a busca por categorias de análise, que permitam compreender a forma como a aprendizagem histórica é mobilizada, exige essas conexões entre os referenciais teóricos e a análise dos dados empíricos. Elas possibilitam, também, à área do Ensino de História, tematizar as experiências dos sujeitos como fundamento para a definição de metas, diretrizes e conteúdos de ensino.

Enfim, os pontos de vista que os sujeitos constroem acerca da História, não dependem somente da forma como se ensina, mas sim dos quadros de referência cultural e subjetiva daqueles que aprendem. Ter em conta esses fatores possibilita entender como, muitas vezes, aquilo que é ensinado não é aprendido, e o que é aprendido não é exatamente o que foi 
ensinado. As limitações desse texto não dão conta de retratar todo o quadro da pesquisa em sua complexidade. Mas creio que o ponto teórico acima foi devidamente esclarecido, e que a análise dos dados permite reflexões sobre a forma como a História pode ser aprendida de forma complexa a partir do trabalho com filmes.

\section{Referências}

A QUEDA! As últimas horas de Hitler. Direção: Oliver Hirschibiegel; Roteiro: Joachim Fest, Traudle Junge e Melissa Muller. Gênero: Drama. Alemanha, 2004. (2h36m).

DAYAN, Daniel. Os mistérios da recepção. In: NÓVOA, Jorge; FRESSATO, Soleni B.; FEIGELSON, Kristian (Org.). Cinematógrafo: um olhar sobre a história. Salvador: Edufbaf; São Paulo: Unesp, 2009. p. 61-83.

FRONZA, Marcelo. A intersubjetividade e a verdade na aprendizagem histórica de jovens estudantes a partir das histórias em quadrinhos. 2012. Tese (Doutorado) - Universidade Federal do Paraná, Curitiba, 2012.

LEE, Peter. Em direção a um conceito de literacia histórica. Educar em Revista, Curitiba, ed. esp., p. 131-150, 2006.

LEE, Peter. Nós fabricamos carros e eles tinham que andar a pé": compreensão das pessoas do passado. In; BARCA, Isabel (Org.). JORNADAS INTERNACIONAIS DE EDUCAÇÃO HISTÓRICA: Educação histórica e museus. 2., 2003, Braga. Actas... Braga: Universidade do Minho, 2003.

O PIANISTA. Direção e Roteiro: Roman Polanski; Gênero: Drama. EUA, 2002. (2h30m).

RÜSEN, Jörn. Esboço de uma teoria da aprendizagem histórica. In:

Aprendizagem histórica: fundamentos e paradigmas. Curitiba: W. A. Editores, 2012.

SCHMIDT, Maria Auxiliadora; BARCA, Isabel. Aprender história: perspectivas da educação histórica. Ijuí: Unijuí, 2009.

SOUZA, Éder C. Cinema e educação histórica: jovens e sua relação com a história em filmes. 2014. Tese (Doutorado em Educação) - Universidade Federal do Paraná, Curitiba, 2014a.

SOUZA, Éder C. Cinema, cultura histórica e didática da história: repensar a relação entre filmes e conhecimento histórico. Revista de Teoria da História, Goiânia, ano 6, n. 12, dez. 2014b. 
SOUZA, Éder C. O uso do cinema no ensino de história: propostas recorrentes, dimensões teóricas e perspectivas da Educação Histórica. Escritas, Tocantins, v. 4, p. 70-93, 2012.

TRIUNFO da vontade. Direção: Leni Riefenstahl. Roteiro: Leni Riefenstahl, Walter Ruttmann, Eberhard Taubert. Gênero: Documentário. Alemanha, 1935. (1h54m).

Recebido em 12 de novembro de 2017 Aprovado em 19 de abril de 2018 